\title{
Role of interleukin-4 genetic polymorphisms and environmental factors in the risk of asthma in children
}

\author{
L. Li, Y. Li, X.C. Zeng, J. Li and X.Y. Du \\ Department of Pediatrics, Weinan Central Hospital, Huainan, China \\ Corresponding author: Y. Li \\ E-mail: jingyangj556@163.com \\ Genet. Mol. Res. 15 (4): gmr15048873 \\ Received June 10, 2016 \\ Accepted September 15, 2016 \\ Published November 3, 2016 \\ DOI http://dx.doi.org/10.4238/gmr15048873
}

Copyright (C) 2016 The Authors. This is an open-access article distributed under the terms of the Creative Commons Attribution ShareAlike (CC BY-SA) 4.0 License.

\begin{abstract}
Asthma is an allergic disease characterized by hyperresponsiveness and chronic inflammation of the airway. The interleukin-4 (IL-4) gene and its single nucleotide polymorphisms are associated with asthma susceptibility in children. A case-control study was performed to evaluate the relationship between asthma risk and the $I L-4$ rs2243250 (589 C/T) and rs2070874 (107 T/C), and IL-4 receptor $(I L-4 R)$ rs1801275 (576 Q/R) polymorphisms in 317 childhood asthma patients and 351 healthy children as controls. Polymerase chain reaction amplification and sequencing was performed. The effects of interactions between the genes of interest and environmental factors were also analyzed. $I L-4$ rs2243250 and rs2070874 allele and genotype frequencies did not significantly differ between the asthma and control groups ( $\mathrm{P}>0.05)$, but those of $I L-4 R$ rs $1801275 \mathrm{did}(\mathrm{P}<0.05)$. The $\mathrm{RR}$ genotype and $\mathrm{R}$ allele of this $I L-4 R$ variant were significantly associated with asthma risk, with odds ratios (ORs; and 95\% confidence intervals) of $2.97(2.08-4.25)$ and 2.99 (2.32-3.85), respectively. Logistic
\end{abstract}


regression analysis showed that the $I L-4 R 576 \mathrm{Q} / \mathrm{R}$ RR genotype demonstrated a positive interaction with environments associated with smoking or pets in its effect on asthma risk, with ORs of $2.18(\mathrm{P}=$ $0.02)$ and $2.29(\mathrm{P}=0.01)$, respectively. Our results suggest that the $I L-4 R$ rs 1801275 polymorphism is associated with childhood asthma, and the RR genotype confers a high risk of developing this condition. This variant exhibited positive interactions with environments in which smoking or pets were present in increasing the risk of childhood asthma.

Key words: $I L-4$; Asthma; Environmental factors; Smoking; Pets

\section{INTRODUCTION}

Asthma is a chronic allergic inflammatory disease of the airway. It is estimated that there are currently 300 million asthma patients worldwide, and the associated morbidity and mortality rates have been steadily increasing (Masoli et al., 2004). The global economic burden of asthma exceeds that of tuberculosis, human immunodeficiency virus infection, and acquired immune deficiency syndrome combined (Wills-Karp et al., 1998), and this disease has become a major public health problem globally (Jaakkola and Jaakkola, 2012).

As a complex disease, the pathogenesis of asthma remains unclear (Cook and Saglani, 2016). However, several studies have shown that it involves inflammatory immune cells (Cook and Saglani, 2016), the secretion of inflammatory mediators, and cytokine interactions (Osei-Kumah et al., 2006), leading to immunoglobulin (Ig) E-mediated hypersensitivity and eosinophil infiltration of the airway, causing chronic inflammation (Wongratanacheewin, 2014). Several complex and diverse risk factors contribute to the development of asthma, involving environment, immunity, lifestyle, and psychology (Hovland et al., 2015; Toskala and Kennedy, 2015; Demirdag and Ramadan, 2016). Many studies concerning this condition have been carried out, mainly focusing on epidemiological and genetic risk factors. It is widely believed that the occurrence of asthma is determined by the compounded effects of numerous genes and environmental aspects, including gene-gene and gene-environment interactions (GonzalezGarcia et al., 2015). In recent decades, single nucleotide polymorphisms have become one of the most commonly studied types of sequence variation in investigations of the relationship between genetics and disease susceptibility (Sengler et al., 2002; Tulah et al., 2013).

Interleukin-4 (IL-4) is primarily produced by Th2 cells (Smallwood et al., 2016). The biological function of IL-4 principally comprises increasing B cell major histocompatibility complex class II molecule expression, promoting resting B cell FceR expression, elevating secretion of $\operatorname{IgE}$ and $\operatorname{IgG} 1$ in the activation of B cells, and stimulating $\operatorname{IgG}$ to $\operatorname{IgE}$ class switching in an autocrine manner to facilitate the differentiation of Th2 cells, while inhibiting Th1 cell proliferation and the Th1 response (Antczak et al., 2016; Pattnaik et al., 2016).

To date, many investigations have tested the association between $I L-4$ polymorphisms and asthma risk, but their results have not been consistent (Micheal et al., 2013; Tang et al., 2014; Huang et al., 2015; Bal et al., 2016). Therefore, we performed a case-control study to analyze the relationship between three IL-4-related loci [rs2243250 (589 C/T) and rs2070874 $(107 \mathrm{~T} / \mathrm{C})$ in $I L-4$, and rs $1801275(576 \mathrm{Q} / \mathrm{R})$ in the IL-4 receptor $\alpha$-chain gene $(I L-4 R)]$ and risk of childhood asthma. Moreover, the effects of interactions between environmental factors and genotypes on risk were also assessed.

Genetics and Molecular Research 15 (4): gmr15048873 


\section{MATERIAL AND METHODS}

\section{Subjects}

From March 2012 to March 2016, we continuously recruited 317 patients with asthma at the Weinan Central Hospital Department of Pediatrics. Asthma was diagnosed according to the Global Initiative for Asthma guidelines (Borish, 2010). Cases were graded by severity according to clinical features into intermittent, mild sustained, moderate continued, and severe sustained categories. Patients with other respiratory diseases, such as recent upper or lower respiratory tract infections, were excluded from our study. A standard questionnaire was filled out by patients or their parents, and pulmonary function, chest X-ray, and other necessary examinations were performed. Diagnosis of atopic disease was based on the skin prick test (SPT).

During the same period, a total of 351 healthy children were selected as a control group. This group comprised individuals having visited our hospital for the treatment of diseases other than asthma or atopic asthma. All subjects were unrelated Han Chinese individuals residing in the vicinity of the hospital, and their parents' consent and cooperation were obtained. This study was approved by the Ethics Committee of our hospital.

\section{Blood samples and DNA extraction}

Between 7:00 and 9:00 a.m., 5-mL blood samples were collected in sterile vacuum tubes containing ethylenediaminetetraacetic acid. Each blood sample was centrifuged at 1300 rpm for 10 min at $4^{\circ} \mathrm{C}$, and the upper plasma layer was stored at $-70^{\circ} \mathrm{C}$, while the buffy coat was preserved at $-20^{\circ} \mathrm{C}$ before extraction of genomic DNA using a QIAamp DNA Blood Mini kit (QIAGEN, Hilden, Germany) following the manufacturer protocol.

\section{Genotyping}

Polymerase chain reaction (PCR) amplification and DNA sequencing were used. Primers were designed with Autoprimer (http://www.autoprimer.com) and synthesized by Shanghai SangGong (Shanghai, China). Primer sequences are shown in Table 1. PCRs consisted of $50-\mu \mathrm{L}$ mixtures containing $75 \mu \mathrm{M}$ deoxynucleotides, 20 ng genomic DNA, 50 $\mathrm{nM}$ primers, $3.5 \mathrm{mM} \mathrm{MgCl}_{2}$, and $0.5 \mathrm{U}$ HotStarTaq polymerase. Using 96-well plates, PCRs were carried out as follows: $95^{\circ} \mathrm{C}$ for $15 \mathrm{~min}$, then 40 cycles of $94^{\circ} \mathrm{C}$ for $30 \mathrm{~s}, 55^{\circ} \mathrm{C}$ for $30 \mathrm{~s}$, and $72^{\circ} \mathrm{C}$ for $60 \mathrm{~s}$, before a final step at $72^{\circ} \mathrm{C}$ for $7 \mathrm{~min}$. PCR products were stored at $4^{\circ} \mathrm{C}$ and subsequently sequenced.

Table 1. Polymerase chain reaction primers used in this study.

\begin{tabular}{l|l|l}
\hline SNP & Primer & Sequence $\left(5^{\prime}-3^{\prime}\right)$ \\
\hline rs2243250 & Forward & AAACTAGGCCTCACCTGATACG \\
\hline$(\mathrm{C} / \mathrm{T})$ & Reverse & TGCATAGAGGCAGAATAACAGG \\
\hline rs2070874 & Forward & GAGGTGAGACCCATTAATAG \\
\hline (T/C) & Reverse & ACGTTGGATGTGCATCGTTAGCTTCTCCTG \\
\hline (Q 1801275 & Forward & GAGGAAGTAGAACCCGAGATGC \\
\hline
\end{tabular}

$\mathrm{SNP}=$ single nucleotide polymorphism. 


\section{Statistical analysis}

SPSS 17.0 (SPSS Inc., Chicago, IL, USA) was used for statistical analysis. Demographic and clinical variables of the patients and controls were compared by the $t$-test or chi-square test. Hardy-Weinberg equilibrium (HWE) of genotype frequencies in the control group was assessed by the goodness-of-fit chi-square test. Differences in genotype, allele, and haplotype frequencies between the patient and control groups were analyzed by chi-square tests, and multiple logistic regression was used to calculate odds ratios (ORs) and 95\% confidence intervals (CIs). We also tested interactions between genotypes and environmental influences, such as smoking, pets, humidity, respiratory infection, and other factors. $\mathrm{P}<0.05$ was considered statistically significant.

\section{RESULTS}

The general characteristics of the patients and control subjects are shown in Table 2. No statistically significant differences in average age or sex were observed between the two groups. Of the 317 asthma patients, $237(75.00 \%)$ had positive SPT results. Concerning disease severity, 70 patients $(22.01 \%)$ presented with intermittent, 50 (15.72\%) with mild sustained, $87(27.36 \%)$ with moderate continued, and 110 (34.91\%) with severe sustained asthma.

Table 2. Comparison of the general characteristics of each study group.

\begin{tabular}{|c|c|c|c|c|c|c|c|c|c|}
\hline & \multirow[t]{2}{*}{$\mathrm{N}$} & \multirow{2}{*}{$\begin{array}{l}\text { Average age } \\
\text { (years) }\end{array}$} & \multicolumn{2}{|c|}{ Gender (\%) } & \multirow{2}{*}{$\begin{array}{c}\text { SPT-positive } \\
(\%)\end{array}$} & \multicolumn{4}{|c|}{ Asthma classification (\%) } \\
\hline & & & Male & Female & & Intermittent & $\begin{array}{c}\text { Mild } \\
\text { sustained }\end{array}$ & Moderate continued & Severe sustained \\
\hline Patients & 317 & $5.80 \pm 4.24$ & $134(42.45)$ & $183(57.55)$ & $237(75.00)$ & $70(22.01)$ & $50(15.72)$ & $87(27.36)$ & $110(34.91)$ \\
\hline Controls & 351 & $6.26 \pm 3.31$ & $151(43.18)$ & $200(56.82)$ & 0 & - & - & - & - \\
\hline$P$ value & & $>0.05$ & & & & & & & \\
\hline
\end{tabular}

$\mathrm{SPT}=$ skin prick test.

$I L-4$ rs2243250 and rs2070874 and $I L-4 R$ rs 1801275 allele frequencies were consistent with HWE $(\mathrm{P}>0.05)$. Comparing the asthma and healthy control groups, no differences in the distribution of $I L-4$ rs 2243250 or rs 2070874 alleles were evident. However, $I L-4 R$ rs 1801275 allele frequencies did significantly differ between these groups $(\mathrm{P}<0.05)$. The $I L-4 R 576 \mathrm{Q} / \mathrm{R}$ $\mathrm{RR}$ genotype and $\mathrm{R}$ allele were significantly more common among asthma patients, with ORs (and 95\%CIs) of 2.97 (2.08-4.25) and 2.99 (2.32-3.85), respectively, as shown in Table 3.

Table 3. Allele and genotype frequencies of the three loci considered in this study.

\begin{tabular}{|c|c|c|c|c|c|c|c|}
\hline Locus & Allele or genotype & Patients [N (\%)] & Controls [N (\%)] & Chi-square & $\mathrm{P}$ & HWE & OR $(95 \% \mathrm{CI})$ \\
\hline \multirow[t]{4}{*}{ rs 2243250} & $\mathrm{~T}$ & $452(71.29)$ & $518(73.79)$ & & & \multirow[t]{4}{*}{0.819} & 1 \\
\hline & $\mathrm{C}$ & $182(28.71)$ & $184(26.21)$ & 1.04 & 0.31 & & $0.88(0.69-1.12)$ \\
\hline & TT & $205(64.67)$ & $213(60.68)$ & & & & 1 \\
\hline & $\mathrm{CC}$ & $112(35.33)$ & $138(39.32)$ & 1.13 & 0.29 & & $1.19(0.87-1.62)$ \\
\hline \multirow[t]{4}{*}{ rs2070874 } & $\mathrm{C}$ & $358(56.47)$ & $416(59.26)$ & & & \multirow[t]{4}{*}{0.12} & 1 \\
\hline & $\mathrm{T}$ & $276(43.53)$ & $286(40.74)$ & 1.07 & 0.30 & & $0.89(0.72-1.11)$ \\
\hline & $\mathrm{CC}$ & $147(46.37)$ & $170(48.43)$ & & & & 1 \\
\hline & TT & $170(53.63)$ & $181(51.57)$ & 0.28 & 0.59 & & $0.92(0.68-1.25)$ \\
\hline \multirow[t]{4}{*}{ rs1801275 } & Q & $386(71.90)$ & $578(85.00)$ & & & \multirow[t]{4}{*}{0.302} & 1 \\
\hline & $\mathrm{R}$ & $248(28.10)$ & $124(15.00)$ & 119.39 & $<0.05$ & & $2.99(2.32-3.85)$ \\
\hline & QQ & $195(61.50)$ & $290(82.62)$ & & & & 1 \\
\hline & $\mathrm{RR}$ & $122(38.50)$ & $61(17.38)$ & 37.31 & $<0.05$ & & $2.97(2.08-4.25)$ \\
\hline
\end{tabular}

$\mathrm{HWE}=$ Hardy-Weinberg equilibrium, $\mathrm{OR}=$ odds ratio, $\mathrm{CI}=$ confidence interval. 
The $I L-4 R 576 \mathrm{Q} / \mathrm{R}$ polymorphism demonstrated a positive interaction with environments affected by smoking (principally those involving family members smoking; OR $=2.18,95 \% \mathrm{CI}=1.15-4.13)$, pets $(\mathrm{OR}=2.29,95 \% \mathrm{CI}=1.22-4.28)$, and damp $(\mathrm{OR}=3.54$, $95 \% \mathrm{CI}=1.99-6.28)$, as displayed in Table 4.

Table 4. Interactions between the $I L-4 R 576 \mathrm{Q} / \mathrm{R}$ polymorphism and environmental factors.

\begin{tabular}{|c|c|c|c|c|c|c|c|c|}
\hline \multicolumn{2}{|l|}{ Factor } & Genotype & B & SE & Wald & $\mathrm{P}$ & OR & $95 \% \mathrm{CI}$ \\
\hline \multirow[t]{2}{*}{ Smoking related-environment } & & QQ & 0.29 & 0.29 & 1.01 & 0.32 & 1.34 & $0.76-2.38$ \\
\hline & & RR & 0.78 & 0.33 & 5.67 & 0.02 & 2.18 & $1.15-4.13$ \\
\hline \multirow[t]{2}{*}{ Pets } & & QQ & 0.11 & 0.28 & 0.15 & 0.7 & 1.12 & $0.65-1.93$ \\
\hline & & $\mathrm{RR}$ & 0.83 & 0.32 & 6.69 & 0.01 & 2.29 & $1.22-4.28$ \\
\hline \multirow[t]{4}{*}{ Humidity } & \multirow[t]{2}{*}{ Damp } & QQ & 0.55 & 0.28 & 3.93 & 0.08 & 1.73 & $1.01-2.98$ \\
\hline & & RR & 1.26 & 0.29 & 8.67 & 0.04 & 3.54 & $1.99-6.28$ \\
\hline & \multirow[t]{2}{*}{ Dry } & QQ & 0.13 & 0.22 & 1.15 & 0.42 & 1.02 & $0.67-1.83$ \\
\hline & & RR & 0.27 & 0.23 & 1.09 & 0.35 & 1.14 & $0.78-2.08$ \\
\hline \multirow[t]{2}{*}{ Respiratory infections } & & QQ & 0.33 & 0.23 & 1.17 & 0.22 & 1.52 & $0.77-1.86$ \\
\hline & & $\mathrm{RR}$ & 0.17 & 0.29 & 1.39 & 0.55 & 1.64 & $0.88-2.02$ \\
\hline
\end{tabular}

$\mathrm{SE}=$ standard error, $\mathrm{OR}=$ odds ratio, $\mathrm{CI}=$ confidence interval.

\section{DISCUSSION}

Bronchial asthma is one of the most common chronic diseases, particularly among children. Approximately $30-50 \%$ of childhood asthma cases persist into adulthood, and an estimated 4.4 million children in the USA suffer from this condition (Eaton et al., 2008; Boulet et al., 2012), with 10.9\% of high school students being affected (Akinbami and Schoendorf, 2002). Asthma may gradually evolve into chronic obstructive pulmonary disease or pulmonary heart disease.

A series of polymorphisms associated with a variety of asthma phenotypes have been identified in the $I L-4$ gene. For instance, it has been suggested previously that the $589 \mathrm{C} / \mathrm{T}$ variant in the $I L-4$ promoter region is connected to decreased FEV1 (Lee et al., 2004). Such relationships have been confirmed in populations in Japan and the USA (Nambu and Holgate, 2009; Zahran and Bailey, 2013), but not China and Arabia (Al-Mazam and Mohamed, 2001; Chen et al., 2013). The $I L-4$ and $I L-13$ genes are located on chromosome 5q31, a site potentially linked to atopic asthma. Other studies have reported that $I L-4 R$ plays an important role in the occurrence of asthma (Cui et al., 2003). The protein encoded by this gene is a key functional component of Th2 cells. IL-4R-deficient mice are unable to produce IgE and exhibit a defective Th2 response, implying that IL-4R is important in IgE regulation, and that corresponding sequence variations can affect signal transduction and increase asthma risk (Barner et al., 1998). IL-4R has been considered as an important candidate gene in atopic asthma susceptibility (Barner et al., 1998). It has been reported that three IL-4R alleles, Ile50, Pro478, and Arg551, are related to susceptibility to asthma. Andrews et al. (2001) analyzed the association between asthma risk and IL-4R $576 \mathrm{Q} / \mathrm{R}$ genotypes, alleles, and haplotypes, finding that these variants are in linkage disequilibrium and are associated with development of atopic asthma. Other studies have also identified Gln576Arg as a risk factor for this condition. For instance, Rosa-Rosa et al. (1999) examined 149 asthma patients and 57 healthy controls, and established a strong association between the IL-4R 576Arg allele and asthma severity, suggesting that $I L-4 R$ is implicated in allergic asthma and may be used as a marker to classify the clinical severity of this disease. In our study, the $I L-4589 \mathrm{C} / \mathrm{T}$ and $107 \mathrm{~T} / \mathrm{C}$ polymorphisms demonstrated no relationship with asthma susceptibility, whereas $I L-4 R 576 \mathrm{Q} / \mathrm{R}$ did. 
However, some previous findings are inconsistent with the results of the present study and those of the above studies. For example, Mak et al. (2007) performed an investigation of 292 asthma patients and 292 healthy controls in Hong Kong, concluding that the $I L-4$ $589 \mathrm{C} / \mathrm{T}$ and $I L-4 R$ Gln576Arg variants do not significantly correlate with asthma risk in this population. Hosseini-Farahabadi et al. (2007) studied 30 asthma patients and 50 normal controls from an Iranian population, and demonstrated an association between IL-4 589 $\mathrm{C} / \mathrm{T}$ and asthma. Kamali-Sarvestani et al. (2007) also confirmed this polymorphism to be associated with this disease in a southern Iranian population. In addition, Li et al. (2008) performed a meta-analysis showing that this sequence variation plays an important role in asthma pathogenesis, although the authors suggested that further work is needed to confirm the mechanism responsible.

In conclusion, we suggest that the RR genotype of the $I L-4 R 576 \mathrm{Q} / \mathrm{R}$ variant may increase risk of asthma, and in exerting this effect, demonstrates a significant interaction with environments associated with smoking and pets. Further studies with large sample sizes are greatly needed to confirm the relationship between $I L-4$ genetic polymorphisms and asthma pathogenesis.

\section{Conflicts of interest}

The authors declare no conflict of interest.

\section{REFERENCES}

Akinbami LJ and Schoendorf KC (2002). Trends in childhood asthma: prevalence, health care utilization, and mortality. Pediatrics 110: 315-322.http://dx.doi.org/10.1542/peds.110.2.315

Al-Mazam A and Mohamed AG (2001). Risk factors of bronchial asthma in bahrah, saudi arabia. J. Family Community Med. 8: 33-39.

Andrews RP, Burrell L, Rosa-Rosa L, Cunningham CM, et al. (2001). Analysis of the Ser786Pro interleukin-4 receptor alpha allelic variant in allergic and nonallergic asthma and its functional consequences. Clin. Immunol. 100: 298-304. http://dx.doi.org/10.1006/clim.2001.5082

Antczak A, Domańska-Senderowska D, Górski P, Pastuszak-Lewandoska D, et al. (2016). Analysis of changes in expression of IL-4/IL-13/STAT6 pathway and correlation with the selected clinical parameters in patients with atopic asthma. Int. J. Immunopathol. Pharmacol. 29: 195-204. http://dx.doi.org/10.1177/0394632015623794

Bal SM, Bernink JH, Nagasawa M, Groot J, et al. (2016). IL-1b, IL-4 and IL-12 control the fate of group 2 innate lymphoid cells in human airway inflammation in the lungs. Nat. Immunol. 17: 636-645.http://dx.doi.org/10.1038/ni.3444

Barner M, Mohrs M, Brombacher F and Kopf M (1998). Differences between IL-4R alpha-deficient and IL-4-deficient mice reveal a role for IL-13 in the regulation of Th2 responses. Curr. Biol. 8: 669-672. http://dx.doi.org/10.1016/ $\underline{\mathrm{S} 0960-9822(98) 70256-8}$

Borish L (2010). IL-4 and IL-13 dual antagonism: a promising approach to the dilemma of generating effective asthma biotherapeutics. Am. J. Respir. Crit. Care Med. 181: 769-770. http://dx.doi.org/10.1164/rccm.201002-0147ED

Boulet LP, FitzGerald JM, Levy ML, Cruz AA, et al. (2012). A guide to the translation of the Global Initiative for Asthma (GINA) strategy into improved care. Eur. Respir. J. 39: 1220-1229. http://dx.doi.org/10.1183/09031936.00184511

Chen ZH, Wang PL and Shen HH (2013). Asthma research in China: a five-year review. Respirology 18 (Suppl 3): 10-19. http://dx.doi.org/10.1111/resp.12196

Cook J and Saglani S (2016). Pathogenesis and prevention strategies of severe asthma exacerbations in children. Curr. Opin. Pulm. Med. 22: 25-31.http://dx.doi.org/10.1097/MCP.0000000000000223

Cui T, Wu J, Pan S and Xie J (2003). Polymorphisms in the IL-4 and IL-4R [alpha] genes and allergic asthma. Clin. Chem. Lab. Med. 41: 888-892. http://dx.doi.org/10.1515/CCLM.2003.134

Demirdag YY and Ramadan HH (2016). Direct measurement of upper airway inflammation in children with chronic rhinosinusitis: implications for asthma. Curr. Opin. Allergy Clin. Immunol. 16: 18-23. http://dx.doi.org/10.1097/ ACI.0000000000000237

Genetics and Molecular Research 15 (4): gmr15048873 
Eaton DK, Kann L, Kinchen S, Shanklin S, et al.; Centers for Disease Control and Prevention (CDC) (2008). Youth risk behavior surveillance--United States, 2007. MMWR Surveill. Summ. 57: 1-131.

Gonzalez-Garcia M, Caballero A, Jaramillo C, Maldonado D, et al. (2015). Prevalence, risk factors and underdiagnosis of asthma and wheezing in adults 40 years and older: A population-based study. J. Asthma 52: 823-830.http://dx.doi. org $/ 10.3109 / 02770903.2015 .1010733$

Hosseini-Farahabadi S, Tavakkol-Afshari J, Rafatpanah H, Farid Hosseini R, et al. (2007). Association between the polymorphisms of $I L-4$ gene promoter $(-590 \mathrm{C}>\mathrm{T}), I L-13$ coding region $(\mathrm{R} 130 \mathrm{Q})$ and $I L-16$ gene promoter $(-295 \mathrm{~T}>\mathrm{C})$ and allergic asthma. Iran. J. Allergy Asthma Immunol. 6: 9-14.

Hovland V, Riiser A, Mowinckel P, Carlsen KH, et al. (2015). Early risk factors for pubertal asthma. Clin. Exp. Allergy 45: 164-176. http://dx.doi.org/10.1111/cea.12409

Huang ZY, Cheng BJ, Cai GJ and Zhang BF (2015). Association of the $I L-4 R$ Q576R polymorphism and asthma in the Chinese Han population: a meta-analysis. Genet. Mol. Res. 14: 2900-2911. http://dx.doi.org/10.4238/2015. March.31.21

Jaakkola MS and Jaakkola JJ (2012). Assessment of public health impact of work-related asthma. BMC Med. Res. Methodol. 12: 22. http://dx.doi.org/10.1186/1471-2288-12-22

Kamali-Sarvestani E, Ghayomi MA and Nekoee A (2007). Association of TNF-alpha -308 G/A and IL-4 -589 C/T gene promoter polymorphisms with asthma susceptibility in the south of Iran. J. Investig. Allergol. Clin. Immunol. 17: 361-366.

Lee JH, Park HS, Park SW, Jang AS, et al. (2004). ADAM33 polymorphism: association with bronchial hyper-responsiveness in Korean asthmatics. Clin. Exp. Allergy 34: 860-865.http://dx.doi.org/10.1111/j.1365-2222.2004.01977.x

Li Y, Guo B, Zhang L, Han J, et al. (2008). Association between C-589T polymorphisms of interleukin-4 gene promoter and asthma: a meta-analysis. Respir. Med. 102: 984-992.http://dx.doi.org/10.1016/j.rmed.2008.02.008

Mak JC, Ko FW, Chu CM, Leung HC, et al. (2007). Polymorphisms in the IL-4, IL-4 receptor alpha chain, TNF-alpha, and lymphotoxin-alpha genes and risk of asthma in Hong Kong Chinese adults. Int. Arch. Allergy Immunol. 144: 114-122.http://dx.doi.org/10.1159/000103222

Masoli M, Fabian D, Holt S and Beasley R; Global Initiative for Asthma (GINA) Program (2004). The global burden of asthma: executive summary of the GINA Dissemination Committee report. Allergy 59: 469-478. http://dx.doi. org/10.1111/j.1398-9995.2004.00526.x

Micheal S, Minhas K, Ishaque M, Ahmed F, et al. (2013). IL-4 gene polymorphisms and their association with atopic asthma and allergic rhinitis in Pakistani patients. J. Investig. Allergol. Clin. Immunol. 23: 107-111.

Nambu M and Holgate S (2009). Differences in the asthma treatment of children between europe and Japan: a questionnaire-based survey using model cases. World Allergy Organ. J. 2: 54-56. http://dx.doi.org/10.1097/ WOX.0b013e31819f20eb

Osei-Kumah A, Ammit AJ, Smith R, Ge Q, et al. (2006). Inflammatory mediator release in normal bronchial smooth muscle cells is altered by pregnant maternal and fetal plasma independent of asthma. Placenta 27: 847-852. http:// dx.doi.org/10.1016/j.placenta.2005.08.007

Pattnaik B, Bodas M, Bhatraju NK, Ahmad T, et al. (2016). IL-4 promotes asymmetric dimethylarginine accumulation, oxo-nitrative stress, and hypoxic response-induced mitochondrial loss in airway epithelial cells. J. Allergy Clin. Immunol. 138: 130-141.e9.http://dx.doi.org/10.1016/j.jaci.2015.11.036

Rosa-Rosa L, Zimmermann N, Bernstein JA, Rothenberg ME, et al. (1999). The R576 IL-4 receptor alpha allele correlates with asthma severity. J. Allergy Clin. Immunol. 104: 1008-1014. http://dx.doi.org/10.1016/S0091-6749(99)70082-5

Sengler C, Lau S, Wahn U and Nickel R (2002). Interactions between genes and environmental factors in asthma and atopy: new developments. Respir. Res. 3: 7.http://dx.doi.org/10.1186/rr179

Smallwood DT, Apollonio B, Willimott S, Lezina L, et al. (2016). Extracellular vesicles released by CD40/IL-4-stimulated CLL cells confer altered functional properties to CD4+ T cells. Blood 128: 542-552. http://dx.doi.org/10.1182/ blood-2015-11-682377

Tang L, Lin HG and Chen BF (2014). Association of IL-4 promoter polymorphisms with asthma: a meta-analysis. Genet. Mol. Res. 13: 1383-1394. http://dx.doi.org/10.4238/2014.February.28.11

Toskala E and Kennedy DW (2015). Asthma risk factors. Int. Forum Allergy Rhinol. 5 (Suppl 1): S11-S16. http://dx.doi. org/10.1002/alr.21557

Tulah AS, Holloway JW and Sayers I (2013). Defining the contribution of SNPs identified in asthma GWAS to clinical variables in asthmatic children. BMC Med. Genet. 14: 100. http://dx.doi.org/10.1186/1471-2350-14-100

Wills-Karp M, Luyimbazi J, Xu X, Schofield B, et al. (1998). Interleukin-13: central mediator of allergic asthma. Science 282: 2258-2261. http://dx.doi.org/10.1126/science.282.5397.2258

Wongratanacheewin S (2014). Update of cytokines and genes in asthma and allergic rhinitis. Asian Pac. J. Allergy Immunol. 32: 275.

Zahran HS and Bailey C (2013). Factors associated with asthma prevalence among racial and ethnic groups--United States, 2009-2010 behavioral risk factor surveillance system. J. Asthma 50: 583-589. http://dx.doi.org/10.3109/027 $\underline{70903.2013 .794238}$

Genetics and Molecular Research 15 (4): gmr15048873 